\title{
Therapeutic Effect of Thymoquinone Against Methotrexate- Induced Damage on Sperm Parameters in Mice
}

\author{
Efecto Terapéutico de la Tiroyoquinona Contra el Daño Inducido \\ por Metotrexato en los Parámetros Espermáticos en Ratones
}

Fatemeh shikhbahaei ${ }^{1}$; Ali Ghanbari² \& Zahra Keshtmand ${ }^{3}$

SHIKHBAHAEI, F.; GHANBARI, A. \& KESHTMAND, Z. Therapeutic effect of thymoquinone against methotrexate-induced damage on sperm parameters in mice. Int. J. Morphol., 36(2):519-522, 2018.

SUMMARY: Methotrexate drug is commonly used to treat cancer; it is known to cause reproductive damage. Thymoquinone, as a natural component of herbs has many healthy benefits shown in researches. The present study aimed to investigate probable therapeutic effects of Thymoquinone against Methotrexate-induced damage on sperm parameters in mice. In this experimental study, 30 male mice (25-30 g) were divided into five groups of six in each group. The mice were received normal saline (control group), Methotrexate (20 $\mathrm{mg} / \mathrm{kg})$, Methotrexate $(20 \mathrm{mg} / \mathrm{kg})$ + Thymoquinone $(2,10$ and $20 \mathrm{mg} / \mathrm{kg})$ by intraperitoneal injection. On the day after the last injection, the sperm parameters including motility, viability and count of sperms were assessed. Data analysis was performed using one-way ANOVA followed by Tukey test. Methotrexate alone showed a significant reduction in sperm parameters compared to the control group $(\mathrm{P}=0.00)$. In groups treated with Methotrexate and Thymoquinone, sperm parameters (motility, viability, count sperm) did not show any significant differences with control group $(\mathrm{P}=0.00)$. Thymoquinone, as a potent antioxidant, could compensate for the toxicity induced by Methotrexate. These medical trends may be useful for diminishing the side effects of Methotrexate on the male reproductive system.

KEY WORDS: Thymoquinone; Methotrexate; Sperm; Mice.

\section{INTRODUCTION}

Methotrexate (MTX) as a mild immunosuppressant drug, exhibiting anti-inflammatory activity, has been represented for the treatment of some cancers (Sussman \& Leonard, 1980). However, studies in animals have shown degeneration in cellular component of seminiferous tubules affecting spermatogenesis (Morris et al., 1993) and in men, some reports of oligospermia outbreak in psoriasis patients, both following undertaking MTX (Badri et al., 2000). These harmful side effects of MTX on male reproductive system, as a part of its adverse effects, have limited the application of the drug. Researches have attempted to overcome this limitation by following trends such as co-administration with natural products. Plants and their derivatives play a key role in world health, and thirty percent of all modern drugs are developed from these natural resources (Burns, 2000). Furthermore, in folk medicine plants have long been used in aiding fertility, including fertility-enhancing properties and aphrodisiac qualities (McDonald, 2004; D'Cruz et al., 2010).
Nigella sativa L. belongs to the botanical family of ranunculaceae (Ali \& Blunden, 2003). It has been known as black seed and its seeds are frequently used in folk medicine in Middle Eastern and some Asian countries for the promotion of good health and treatment of many ailments (El-Kadi \& Kandil, 1987; Kumara \& Huat, 2001). Nigella Sativa seed contains a complex mixture of more than 100 constituents . Most of the therapeutic properties of Nigella sativa are due to the presence of a polyphenol compound named Thymoquinone (TQ) (Ahmad et al., 2013) which is the major ingredient of Nigella sativa oil (28-57\%) (Ali \& Blunden; Pari et al., 2010).

The pharmacological investigations confirmed antioxidant activity of Thymoquinone. Antioxidant property of Thymoquinone is attributed to the quinine structure of Thymoquinone molecule (Gökçe et al., 2011) which easy accesses to sub-cellular compartments facilitating the ROS

\footnotetext{
'Department of Anatomy Afzalpour School of Medicine, Kerman University of Medical Science, Kerman, Iran.

${ }^{2}$ Medical Biology Research Center, Kermanshah University of Medical Sciences, Kermanshah, Iran.

${ }^{3}$ Department of Biology,Central Tehran Branch, Islamic Azad University, Tehran, Iran.
} 
scavenging (Badary et al., 2000). Thymoquinone was also shown to inhibit nonenzymatic lipid peroxidation (Ismail et al., 2010). Previous data suggest that the seeds oil and Thymoquinone exhibited sperm protective effect against testes damage.

Therefore, regard to value of plant used in traditional medicine for drug discovery of fertility-enhancing, this study was conducted to examine the effect of Thymoquinone against Methotrexate-Induced damage on sperm parameters in mice.

\section{MATERIAL AND METHOD}

Animals. Thirty male Balb/c mice with weight of $25-30 \mathrm{~g}$ were used. Animals were kept in the temperature of $22 \pm 2$ ${ }^{\circ} \mathrm{C}$ under controlled environmental conditions, 12-hour light-dark cycles and fed standard pellet chow and water ad libitum. All experiments procedures were conducted in accord with the principles for the care and use of laboratory animals in research and approved by the ethics committee at our university.

Experiment protocol. The animals were divided randomly into following 5 groups $(n=6)$ : i. Control group receiving dimethyl sulfoxide (DMSO, 1:1000) in normal saline, ii. Experimental group (E1) receiving only an intraperitoneal single dose injection of MTX $(20 \mathrm{mg} / \mathrm{kg}$; Sigma Aldrich, USA), iii. Experimental groups (E2-E4) receiving an intraperitoneal injection of MTX $(20 \mathrm{mg} / \mathrm{kg})$ plus TQ (Sigma Aldrich, USA) in different concentrations of $2 \mathrm{mg} / \mathrm{kg}$ (E2), $10 \mathrm{mg} / \mathrm{kg}$ (E3), and $20 \mathrm{mg} / \mathrm{kg}$ (E4). Experimental groups were treated over period of 4 consecutive days (16).

Analysis of sperm parameter. The left cauda epididymis was separated and chopped in DMEM/F12 containing $5 \%$ FBS which had been balanced in the incubator previously; it was then placed in incubator with the temperature of $37^{\circ} \mathrm{C}$ and $5 \% \mathrm{CO}_{2}$. To count the sperms, the solution was transferred into each chamber of Neubauer hemocytometer and sperm heads was manually counted under a microscope. Sperm count was performed according to WHO guidelines and data were expressed as the number of sperm $/ \mathrm{ml}$. The sperm motility was divided into four levels (48): (0): without motility, (I): minor in situ motility. (II): circumferential motility and (III): progressive motility. A minimum of five microscopic fields were assessed to evaluate sperm motility on at least 200 sperm for each animal. For the assessment of viability we used eosin staining that discriminates life sperm from dead sperm by staining cytoplasm of cell. At least 200 sperm were counted for each animal and discriminate live sperm that was not stained and dead sperm that was red (Keshtmand et al., 2014).

Statistical analysis. Results were analyzed using spss 19 (SPSS Inc, Chicago, Illinois) and expressed as means \pm SE. Statistical significant different was determined by one- way analysis of variance (ANOVA) followed by Tukey, s post hoc test for multiple comparison. Probability values $(\mathrm{P})$ less than 0.05 were considered to be statistically significant.

\section{RESULTS}

The results of the sperm viability showed a significant increase in live sperm in E3 and E4 groups as compared to that of the MTX group (Fig. 1a).

Sperm motility and percentage of progressively motile sperm in experimental groups in comparison with MTX group had significant increase (Fig .1b).

According to statistical analysis count of sperm in second (MTX+2 mg/kg of TQ), third (MTX+10 mg/kg of TQ) and fourth (MTX+20 mg/kg of TQ) experimental group in comparison with MTX group no significant increase (Fig. 1c).

\section{DISCUSSION}

In the present study, the Therapeutic effect of TQ against Methotrexate -induced cytotoxicity in mice was evaluated. The results showed a significant decline in the sperm parameters of animals treated with Methotrexate.

Methotrexate is a well-known anti-cancer agent used for the treatment of malignant and non-malignant conditions. In recent years, large number of reports have been published on potential gonadal damage following drug toxicity by anticancer drugs both on cellular and molecular aspects during spermatogenesis. Gonad is an important component of reproductive system, associated with series of cellular interaction, differentiation to form mature germ cells through process of spermatogenesis. Any insult at this stage on gonads may impair fertility. 3-13,15,16 Previous study also indicated that low dose of MTX affects cellular contents, diameter of seminiferous tubules and interstitial space of testis during spermatogenesis (Sussman \& Leonard; Badri et al.). 
SHIKHBAHAEI, F.; GHANBARI, A. \& KESHTMAND, Z. Therapeutic effect of thymoquinone against methotrexate-induced damage on sperm parameters in mice. Int. J. Morphol., 36(2):519-522, 2018.
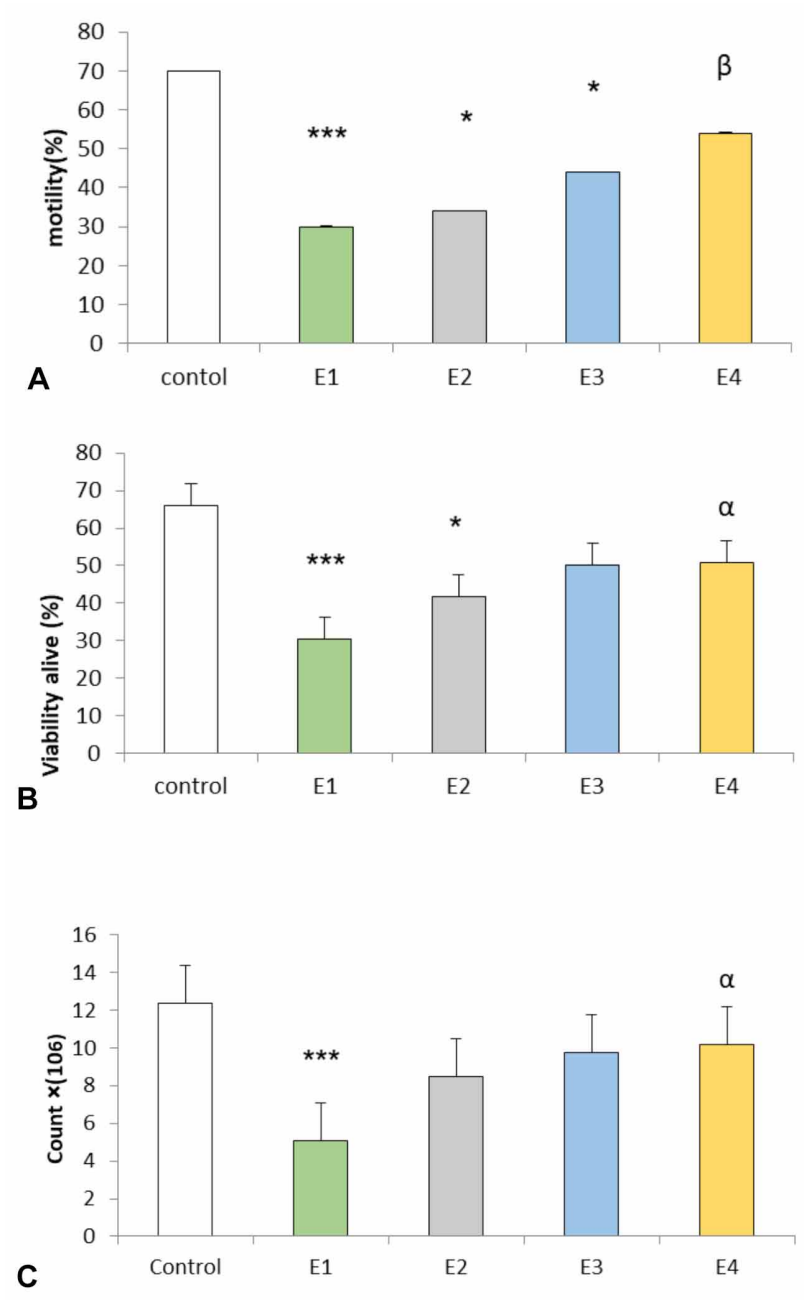

Fig.1. The effect of toxic dose of MTX $(20 \mathrm{mg} / \mathrm{kg})$ and different doses of TQ on a: viability sperm b: total motility of sperms, c: sperm count, The groups (X axis) are Control: not treated, E1: MTX $20 \mathrm{mg} / \mathrm{kg}, \mathrm{E} 2: \mathrm{MTX}+\mathrm{TQ}(2.5 \mathrm{mg} / \mathrm{kg}), \mathrm{E} 3: \mathrm{MTX}+\mathrm{TQ}(10$ $\mathrm{mg} / \mathrm{kg}), \mathrm{E} 4: \mathrm{MTX}+\mathrm{TQ}(20 \mathrm{mg} / \mathrm{kg}) . * \mathrm{P}<0.05$ compared to the control group. $* * * \mathrm{P}<0.000$ compared to the control group and a $\mathrm{P}<0.05$ compared to the MTX group, $\mathrm{b} \mathrm{P}<0.01$ compared to the MTX group.TMX= Methotrexate, $\mathrm{TQ}=$ Thymoquinone.

Infertility is a complex disorder with significant medical, psychosocial and economic aspects. About $25 \%$ of couples do not achieve pregnancy within 1 year, $15 \%$ of whom seek medical treatment for infertility and less than 5 $\%$ remain childless. Infertility affects both men and women. Male causes for infertility are found in $50 \%$ of involuntarily childless couples (World Health Organization, 2000).

A wide majority of medicinal plants possess pharmacological principles, which has rendered them useful as curatives for numerous ailments. According to the World Health Organization (WHO) reports, 70-80\% of the world population confide in traditional medicine for primary health care (World Health Organization).

TQ is the major active component derived from Nigella sativa and reported that many of the pharmacodynamic effects. Nigella sativa are due to TQ (AlAli et al., 2008; Gökçe et al., 2010). TQ treatment has protective effects on testicular parameters. The results of the present study are in correlating with previous studies and confirmed that the testicular favoring results due to TQ content in Nigella sativa seed. Therefore, Thymoquinone may be used for increasing testicular activity.

Several case reports and series have documented reversible sterility in men using Methotrexate (Van Scott \& Reinertson, 1959; Günther, 1970).

They reported a decrease in sperm count or quality with use of the agent. When the medication was discontinued, the sperm returned to normal levels and quality. Replicate DNA due to inhibition of an essential enzyme dihydrofolate reductase required for normal DNA synthesis (Ismail et al.). Therefore, it can be concluded that these qualitative and quantitative changes in male gonads may alter the reproductive performance of animals, if not reversible in nature. However, further study is required at ultra-structural and molecular level to explore the mechanism of action of methotrexate. De Luca et al. (1971( also reported minimal to no suppression of spermatogenesis with methotrexate therapy.

Oxidative stress is harmful to sperm function and a significant factor in the etiology of male infertility (Makker et al., 2009) In addition, oxidative stress impairs male fertility by changing the cell function like sperm motility, increase in DNA damage by induction of gene mutations, DNA denaturation, base pair oxidation and DNA fragmentation (Agarwal \& Said, 2005).

Many factors lead to the sperm abnormality especially sperm without head. Lipid peroxidation and accumulation of free radicals cause morphological damage of sperm (Scibona et al., 1994).

\section{CONCLUSION}

In conclusion, present study demonstrated that the therapeutic effect of Thymoquinone against MethotrexateInduced damage on sperm parameters in Mice. Thymoquinone as antioxidants may improve fertility by means of increasing the sperm parameters. 
The authors thank the Kermanshah University of Medical Science Research fund for providing us with financial support on this work by grant no 90057.

SHIKHBAHAEI, F.; GHANBARI, A. \& KESHTMAND, Z. Efecto terapéutico de la tiroyoquinona contra el daño inducido por metotrexato en los parámetros espermáticos en ratones. Int. J. Morphol., 36(2):519-522, 2018.

RESUMEN: El metotrexato es un fármaco utilizado comúnmente para tratar el cáncer pero además causa daño en los órganos reproductivos. Durante las investigaciones se ha demostrado que la timoquinona, un componente natural de las hierbas, tiene numerosos beneficios. El objetivo del estudio fue investigar el probable efecto terapéutico de la timoquinona contra el daño inducido por metotrexato, en los parámetros espermáticos en ratones. En este estudio experimental, se dividieron 30 ratones machos (25-30 g) en cinco grupos de seis en cada uno. Los ratones recibieron solución salina normal (grupo control), metotrexato (20 $\mathrm{mg} / \mathrm{kg})$, metotrexato $(20 \mathrm{mg} / \mathrm{kg})+$ timoquinona $(2,10$ y $20 \mathrm{mg} /$ $\mathrm{kg}$ ) por inyección intraperitoneal. El día después de la última inyección, se evaluaron los parámetros espermáticos, incluida la motilidad, la viabilidad y el recuento de espermatozoides. El análisis de los datos se realizó utilizando test de ANOVA seguido de la prueba de Tukey. Durante el uso exclusivo de metotrexato se observó una reducción significativa en los parámetros espermáticos en comparación con el grupo control $(\mathrm{P}=0.00)$. En los grupos tratados con metotrexato y timoquinona, los parámetros espermáticos (motilidad, viabilidad, conteo de espermatozoides) no mostraron diferencias significativas con el grupo control $(\mathrm{P}=$ 0.00). Como potente antioxidante, la timoquinona podría compensar la toxicidad inducida por metotrexato. Estas tendencias médicas pueden ser útiles para disminuir los efectos secundarios de metotrexato en el sistema reproductivo masculino.

PALABRAS CLAVE: Timoquinona; Metotrexato; Esperma; Ratón.

\section{REFERENCES}

Agarwal, A. \& Said, T. M. Oxidative stress, DNA damage and apoptosis in male infertility: a clinical approach. B. J. U. Int., 95(4):503-7, 2005.

Ahmad, A.; Husain, A.; Mujeeb, M.; Khan, S. A.; Najmi, A. K.; Siddique, N. A.; Damanhouri, Z. A. \& Anwar, F. A review on therapeutic potential of Nigella sativa: A miracle herb. Asian Pac. J. Trop. Biomed., 3(5):337-52, 2013.

Al-Ali, A.; Alkhawajah, A. A.; Randhawa, M. A. \& Shaikh, N. A . Oral and intraperitoneal LD50 of thymoquinone, an active principle of Nigella sativa, in mice and rats. J. Ayub. Med. Coll. Abbottabad., 20(2):25-27, 2008.

Ali, B. H. \& Blunden, G. Pharmacological and toxicological properties of Nigella sativa. Phytother. Res., 17(4):299-305, 2003.

Badary, O. A.; Abdel-Naim, A. B.; Abdel-Wahab, M. H . \& Hamada, F. M. The influence of thymoquinone on doxorubicin-induced hyperlipidemic nephropathy in rats. Toxicology, 143(3):219-26, 2000.

Badri, S. N.; Vanithakumari, G. \& Malini, T. Studies on methotrexate effects on testicular steroidogenesis in rats. Endocr. Res., 26(2):247-62, 2000.

Burns, M. M. Alternative medicine: Herbal preparation. Clin. Pediatr. Emerg. Med., 1(3):186-90, 2000.

D'Cruz, S. C.; Vaithinathan, S.; Jubendradass, R. \& Mathur, P. P. Effects of plants and plant products on the testis. Asian J. Androl., 12(4):468-79, 2010.

De Luca, M.; Ciampo, E. \& Rossi, A. Study of the seminal fluid in subjects treated with methotrexate. G Ital. Dermatol. Minerva Dermatol., 46(6):247-9, 1971.

El-Kadi, A. \& Kandil, O. The black seed (Nigella sativa) and immunity: Its effect on human T cell subset. Fed. Proc., 46:1222, 1987.

Gökçe, A.; Oktar, S.; Koc, A. \& Yonden, Z. Protective effects of thymoquinone against methotrexate-induced testicular injury. Hum. Exp. Toxicol, 30(8):897-903, 2011.

Gökçe, A.; Oktar, S.; Koc, A.; Gonenci, R.; Yalcinkaya, F.; Yonden, Z. \& Duru, M. Protective effect of thymoquinone in experimental testicular torsion. Urol. Int., 85(4):461-5, 2010.

Günther, E. Andrologic examinations in the antimetabolite therapy of psoriasis. Dermatol Monatsschr.,156(5):498-502, 1970.

Ismail, M.; Al-Naqeep, G. \& Chan, K. W. Nigella sativa thymoquinone-rich fraction greatly improves plasma antioxidant capacity and expression of antioxidant genes in hypercholesterolemic rats. Free Radic. Biol. Med., 48(5):664-72, 2010.

Keshtmand, Z.; Oryan, S.; Ghanbari, A. \& Khazaei, M. Protective effect of Tribulus terrestris hydroalcoholic extract against cisplatin-induced cytotoxicity on sperm parameters in male mice. Int. J. Morphol., 32(2):551-7, 2014.

Kumara, S. S. \& Huat, B. T. Extraction, isolation and characterisation of antitumor principle, alpha-hederin, from the seeds of Nigella sativa. Planta Med., 67(1):29-32, 2001.

Makker, K; Agarwal, A. \& Sharma, R. Oxidative stress \& male infertility. Indian J. Med. Res, 129(4):357-67, 2009.

McDonald, A. A Botanical Perspective on the Identity of Soma (Nelumbo nucifera Gaertn.) Based on Scriptural and Iconographic Records. New York, Botanical Garden Press, 2004.

Morris, L. F.; Harrod, M. J.; Menter, M. A. \& Silverman, A. K. Methotrexate and reproduction in men: case report and recommendations. J. Am. Acad. Dermatol., 29(5 Pt. 2):913-6, 1993.

Pari, L.; Srinivasan, S. \& Saddiq, M. Preventive effect of diosmin, a bioflavonoid, on glycoprotein changes in streptozotocin-nicotinamideinduced type 2 diabetic rats. Int. J. Pharm. Sci. Res, 12(1):89-95, 2010.

Scibona, M.; Meschini, P.; Capparelli, S.; Pecori, C.; Rossi, P. \& Menchini Fabris, G. F. L-arginine and male infertility. Minerva Urol. Nefrol., 46(4):251-3, 1994.

Sussman, A. \& Leonard, J. M. Psoriasis, methotrexate, and oligospermia. Arch. Dermatol., 116(2):215-7, 1980.

Van Scott, E. J. \& Reinertson, R. P. Morphologic and physiologic effects of chemotherapeutic agents in psoriasis. J. Invest. Dermatol., 33:357-69, 1959.

World Health Organization. WHO Manual for the Standardized Investigation and Diagnosis of the Infertile Couple. Cambridge, Cambridge University Press, 2000.

Corresponding author:

Zahra Keshtmand, Ph.D

Department of Biology, Central Tehran Branch

Islamic Azad University

Tehran

IRAN

Email: zkeshtmand2001@gmail.com

Received: 20-09-2017

Accepted: 03-01-2018 